\title{
Review
}

\section{Characteristics of Intracranial Aneurysms in the Else Kröner-Fresenius Registry of Autosomal Dominant Polycystic Kidney Disease}

\author{
Hartmut P.H. Neumann ${ }^{a}$ Angelica Malinoc ${ }^{a}$ Janina Bacher ${ }^{a}$ \\ Zinaida Nabulsi $^{a}$ Vera Ivanovas ${ }^{b}$ Nadine Ortiz Bruechle ${ }^{g}$ \\ Irina Mader ${ }^{g}$ Michael M. Hoffmann ${ }^{c}$ Peter Riegler ${ }^{j}$ \\ Annette Kraemer-Guth ${ }^{f}$ Christian Burchardi ${ }^{\text {h }}$ Elke Schaeffner ${ }^{i}$ \\ Rodolfo S. Martin ${ }^{k}$ Pablo J. Azurmendik Klaus Zerres ${ }^{\mathrm{g}}$ \\ Cordula Jilg ${ }^{d}$ Charis Engl' Sven Gläsker ${ }^{e}$
}

\begin{abstract}
a Department of Nephrology, Section of Preventive Medicine, and Departments of ${ }^{b}$ Neuroradiology, 'Laboratory Medicine, dUrology and ${ }^{\mathrm{e}}$ Neurosurgery, Albert Ludwig University, and ${ }^{\mathrm{f}}$ Dialysis Training Center,

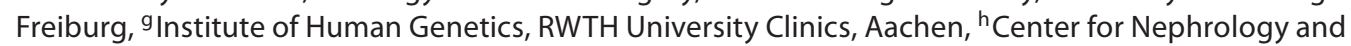
Dialysis, Offenbach, and 'Department of Nephrology, Charité Campus Virchow, Berlin, Germany; ' Center for Nephrology and Dialysis, Merano, Italy; ${ }^{k}$ Instituto de Investigaciones Médicas Alfredo Lanari, Buenos Aires, Argentina; 'Genomic Medicine Institute, Cleveland Clinic, Cleveland, Ohio, USA
\end{abstract}

\section{Key Words}

Intracranial aneurysms - Autosomal dominant polycystic kidney disease $\cdot$ Preventive medicine

\begin{abstract}
Background: Patients who harbor intracranial aneurysms (IAs) run a risk for aneurysm rupture and subsequent subarachnoid hemorrhage which frequently results in permanent deficits or death. Prophylactic treatment of unruptured aneurysms is possible and recommended depending on the size and location of the aneurysm as well as patient age and condition. IAs are major manifestations of autosomal dominant polycystic kidney disease (ADPKD). Current guidelines do not suggest surveillance of IAs in ADPKD except in the setting of family history if IA was known in any relative with ADPKD. Management of IAs in ADPKD is problematic because limited data exist from large studies. Methods: We established the Else Kröner-Fresenius Registry for ADPKD in Germany. Clinical data were assessed for age at diagnosis of IAs, stage of renal insufficiency, and number, location and size of IAs as well as family history of cerebral events. Patients with symptomatic or asymptomatic IAs were included. All patients with ADPKD-related
\end{abstract}

Prof. Dr. Dr. h.c. Hartmut P.H. Neumann Medizinische Universitätsklinik

Abteilung Innere Medizin 4, Hugstetter Strasse 55

DE-79106 Freiburg (Germany)

E-Mail hartmut.neumann@uniklinik-freiburg.de 


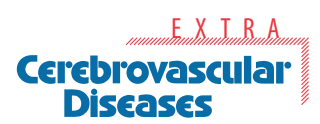

Cerebrovasc Dis Extra 2012;2:71-79

DOI: $10.1159 / 000342620$

Published online: October 9, 2012

Neumann et al.: Characteristics of Intracranial Aneurysms in the Else Kröner-Fresenius

Registry of Autosomal Dominant Polycystic Kidney Disease

IAs were offered mutation scanning of the susceptibility genes for ADPKD, the PKD1 and PKD2 genes. Results: Of 463 eligible ADPKD patients from the population base of Germany, 32 (7\%) were found to have IAs, diagnosed at the age of 2-71 years, 19 females and 13 males. Twenty (63\%) of these 32 patients were symptomatic, whereas IAs were detected in an asymptomatic stage in 12 patients. IAs were multifocal in 12 and unifocal in 20 patients. In 26 patients (81\%), IAs were diagnosed before end-stage renal failure. Twenty-five out of 27 unrelated index cases (93\%) had no IAs or cerebral events documented in their relatives with ADPKD. In 16 unrelated index patients and 3 relatives, we detected germline mutations. The mutations were randomly distributed across the PKD1 gene in 14 and the PKD2 gene in 2 index cases. Questionnaires answered for 320/441 ADPKD patients without IAs revealed that only 45/320 (14\%) had MR angiography. Conclusion: In ADPKD, rupture of IAs occurs frequently before the start of dialysis, is only infrequently associated with a family history of IAs or subarachnoid hemorrhage, and is associated with mutations either of the PKD1 or the PKD2 gene of any type. Screening for IAs is widely insufficiently performed, should not be restricted to families with a history of cerebral events and should be started before end-stage renal failure.

Copyright $\odot 2012$ S. Karger AG, Basel

\section{Introduction}

A number of inherited disorders predispose to intracranial aneurysms (IAs). Hereditary IAs are most frequently observed in patients with autosomal dominant polycystic kidney disease (ADPKD) [1], but can also occur in autosomal recessive PKD [2]. Several groups have reported a 5-10\% prevalence of IAs in ADPKD [3-5]. In ADPKD, IAs may occur in several family members affected by PKD [4].

IAs are associated with a risk for rupture [6,7]. Subsequent subarachnoid hemorrhage frequently causes death or permanent neurological symptoms and deficits. The classic Hunt and Hess grading scale is commonly utilized for classification of the severity of subarachnoid hemorrhage [8]. Thus, if risk of aneurysmal rupture can be predicted beforehand, prevention of high-risk cases should be the strategy. The development of microneurosurgery and endovascular therapy provides excellent possibilities of such preventive treatment of unruptured aneurysms. Treatment of asymptomatic aneurysms is recommended depending on the size and location of the aneurysm as well as patient age and condition $[9,10]$. However, prophylactic treatment cannot be administered in most cases of innocent IAs, since asymptomatic carriers of unruptured IAs are usually not diagnosed. Therefore, a potential but paramount approach is the identification of subsets of high-risk patients, such as those with hereditary disorders associated with IAs. Despite the belief that the prevalence of IAs is high in ADPKD, screening for IAs in individuals without a family history of IAs is not recommended [11, 12]. Since studies on ADPKD-associated IAs are limited, we analyzed IAs in a large populationbased ADPKD registry for adequate management.

\section{Material and Methods}

We have established the Else Kröner-Fresenius Registry for ADPKD, with prospective accrual from 2005 onwards. For purposes of this study, registrants accrued between 2005 and the end of 2011 were considered. Patients were initially registered from the population base of southwestern Germany, and subsequently also from nephrology centers throughout Germany. All patients with ADPKD who were willing to provide clinical data were registered. Registrants were asked by questionnaire for information on age, gender, race, serum 
creatinine, results of abdominal ultrasonography, blood pressure values, and data from affected family members. We re-evaluated all diagnoses of ADPKD to ensure diagnoses were in accordance with internationally accepted criteria [12]. For patients with IA and ADPKD, a subsequent supplementary questionnaire was sent to the patients' and their healthy relatives' healthcare providers asking for the date of diagnosis of IA, location, number and size of IAs, symptoms, treatment, and outcome. The clinics where the patients were diagnosed and treated were contacted and asked for the neuroradiological documents and the clinical data of the patients. Another supplementary questionnaire was sent to the patients without IAs and their providers asked for neuroradiological imaging used for exclusion of IAs.

All patients were asked for $10 \mathrm{ml}$ EDTA-anticoagulated blood for molecular genetic analyses. From these samples, genomic DNA was extracted using standard methods. Subsequently, the genes $P K D 1$ and $P K D 2$ were analyzed using techniques reported by us [13]. In brief, we analyzed all exons of the $P K D 1$ and $P K D 2$ genes primarily using denaturing highperformance liquid chromatography (DHPLC) as shown by Rossetti et al. [14]. If DHPLC revealed an abnormal chromatography, sequencing of the affected exon was performed. In order to exclude analyses of pseudogenes, we performed long-range PCR with 5 overlapping amplicons for the analysis of PKD1 exons 1-32.

We compared all identified germline variants to those listed in the PKD foundation database at http://pkdb.mayo.edu/cgi-bin/mutations.cgi. In particular, we used in silico analysis for all detected missense DNA variants for potential pathogenicity using the programs SIFT, PolyPhen, SNAP, and Mutation Taster [15-19]. In addition, we checked whether the sequences containing the variant were highly conserved using the website http://www.ensembl.org. Finally, we sequenced the affected exons in 100 control blood samples from volunteers of the Freiburg blood bank.

All patients provided written informed consent. The Ethical Committee of the University Medical Center of the Albert Ludwig University Freiburg, Germany, approved the study.

\section{Results}

As of December 31, 2011, the Else Kröner-Fresenius Registry for ADPKD comprised 463 unrelated individuals for whom information regarding IAs was available. Of the 463 patients, 32 (6.9\%; 19 females, 13 males) had IAs. Age at diagnosis of IAs was 2-71 (mean 42.9) years, and only 4 patients were younger than 30 years. Clinical characteristics are shown in table 1 . IAs were symptomatic in $20 / 32$ patients $(63 \%)$ because of subarachnoid hemorrhage and asymptomatic in 12 patients. A history of IAs and ADPKD initiated neuroimaging in 2 members of one family who showed such lesions. Other asymptomatic IAs were detected in 10 patients who had ADPKD but no relatives affected by IAs.

Radiological documentation of IAs was available from 29 of the 32 patients reported to have IAs, i.e. radiologic documentation of 48 IAs was available from a total of 51 IAs. Twelve patients had $>1$ IA. Of the 48 documented IAs, the location and distribution were as follows: along the middle cerebral artery $(n=19)$, anterior communicating artery $(n=10)$, ophthalmic artery $(n=6)$, internal carotid artery $(n=3)$, pericallosal artery $(n=3)$, the callosomarginal artery $(n=2)$, posterior communicating artery $(n=1)$, posterior inferior cerebellar artery $(n=1)$, vertebral artery $(n=1)$, proximal anterior cerebral artery $(n=1)$ and basilar $\operatorname{artery}(\mathrm{n}=1)$.

In 26 patients (81\%), IAs were diagnosed before end-stage renal failure. Twenty-five out of 27 index cases $(93 \%)$ had a family history without IAs when the IAs were detected.

Treatment included neurosurgical procedures with clipping of the IAs in 19 patients. Endovascular treatment with coiling of the aneurysms was performed in 7 patients. Two ad- 
Table 1. Clinical characteristics of patients with IAs and mutations in the PKD1 or PKD2 gene

\begin{tabular}{|c|c|c|c|c|c|c|c|c|c|}
\hline $\begin{array}{l}\text { Case } \\
\text { No. }\end{array}$ & Sex & $\begin{array}{l}\text { Age at } \\
\text { diagnosis } \\
\text { of IA } \\
\text { years }\end{array}$ & $\begin{array}{l}\text { Symptoms, } \\
\text { HH scale }\end{array}$ & Location of IAs & IAs, $n$ & Size of IA, mm & Therapy & $\begin{array}{l}\text { Diagnosis } \\
\text { of IA before } \\
\text { ESRF }\end{array}$ & $\begin{array}{l}\text { Family history of } \\
\text { IAs }\end{array}$ \\
\hline 1 & M & 49 & sy & $\begin{array}{l}\text { right and left middle cerebral } \\
\text { artery }\end{array}$ & 2 & $\begin{array}{l}8 \times 8 \times 8 \\
10 \times 10 \times 10\end{array}$ & clip & no & no \\
\hline 2 & $\mathrm{~F}$ & 32 & asy & $\begin{array}{l}\text { left posterior inferior cerebellar } \\
\text { artery }\end{array}$ & 1 & $4.8 \times 3.4$ & clip & yes & $\begin{array}{l}\text { no; } \\
\text { relative of } \\
\text { case } 22\end{array}$ \\
\hline 3 & M & 46 & asy & left internal carotid artery & multiple & n.a. & no & yes & no \\
\hline 4 & M & 36 & asy & $\begin{array}{l}2 \times \text { anterior communicating } \\
\text { artery }\end{array}$ & 2 & n.a. & $\operatorname{coil} 2 \times$ & yes & no \\
\hline 5 & M & 50 & asy & right middle cerebral artery & 1 & $4 \times 4$ & clip & yes & $\begin{array}{l}\text { relative of } \\
\text { cases } 6 \text { and } 29\end{array}$ \\
\hline 6 & M & 46 & asy & right middle cerebral artery & 1 & n.a. & no & yes & $\begin{array}{l}\text { relative of } \\
\text { cases } 5 \text { and } 29\end{array}$ \\
\hline 7 & M & 43 & asy & right middle cerebral artery & 1 & $5.1 \times 4.7 \times 4.6$ & clip & yes & $\begin{array}{l}\text { yes; } \\
\text { relative of } \\
\text { cases } 12 \text { and } 20\end{array}$ \\
\hline 8 & $\mathrm{~F}$ & 71 & asy & right middle cerebral artery & 1 & n.a. & no & no & no \\
\hline 9 & $\mathrm{~F}$ & 43 & asy & $\begin{array}{l}\text { right middle cerebral artery, } \\
\text { callosomarginal artery, } \\
\text { ophthalmic artery, } \\
\text { left middle cerebral artery }\end{array}$ & 4 & $\begin{array}{l}\text { ophthalmic left } \\
7.5 \times 5 \text {; right } \\
\text { middle cerebral } \\
\text { artery } 4 \times 6\end{array}$ & clip media right & no & no \\
\hline 10 & $\mathrm{~F}$ & 47 & asy & $\begin{array}{l}\text { middle cerebral artery, } \\
\text { anterior communicating artery }\end{array}$ & 2 & n.a. & clip & yes & no \\
\hline 11 & $\mathrm{~F}$ & 50 & asy & internal carotid artery & 1 & $2 \times 3 \times 3$ & no treatment & yes & no \\
\hline 12 & M & 41 & asy & basilar artery & 1 & $9.5 \times 5.5 \times 4$ & coil & yes & $\begin{array}{l}\text { yes; } \\
\text { relative of } \\
\text { cases } 7 \text { and } 20\end{array}$ \\
\hline 13 & $\mathrm{~F}$ & 34 & asy & $\begin{array}{l}\text { left middle cerebral artery, } \\
\text { left pericallosal artery, } \\
\text { left ophthalmic artery }\end{array}$ & 3 & n.a. & $\begin{array}{l}\text { clip } 1 \times \text {, coil } 1 \times \text {, } \\
1 \text { not treated }\end{array}$ & no & no \\
\hline 14 & M & 47 & headache & $\begin{array}{l}\text { right middle cerebral artery } \\
\text { and ophthalmic artery }\end{array}$ & 2 & n.a. & $\operatorname{clip} 1 \times$ & yes & no \\
\hline 15 & $\mathrm{~F}$ & 49 & HH1 & right middle cerebral artery & 1 & $4.2 \times 4.5$ & clip & yes & $\begin{array}{l}\text { mother with } \\
\text { cerebral } \\
\text { aneurysm }\end{array}$ \\
\hline 16 & $\mathrm{~F}$ & 55 & $\mathrm{HH} 4$ & right pericallosal artery & 1 & $3.7 \times 3 \times 4.5$ & coil & yes & no \\
\hline 17 & $\mathrm{~F}$ & 45 & $\mathrm{HH} 4$ & right middle cerebral artery & 1 & $6 \times 6$ & coil & yes & no \\
\hline 18 & $\mathrm{~F}$ & 38 & SAB & n.a. & 1 & n.a. & clip & yes & no \\
\hline 19 & $\mathrm{~F}$ & 31 & $\mathrm{SAB}$ & $\begin{array}{l}\text { anterior cerebral artery, } \\
\text { anterior communicating artery }\end{array}$ & 2 & n.a. & $\begin{array}{l}\text { coil } 1 \times, 1 \\
\text { not treated }\end{array}$ & yes & no \\
\hline 20 & M & 43 & $\mathrm{SAB}, \mathrm{HH} 1$ & $\begin{array}{l}\text { left posterior communicating } \\
\text { artery }\end{array}$ & 1 & $2.9 \times 2.2 \times 2.8$ & clip & yes & $\begin{array}{l}\text { yes; } \\
\text { relative of } \\
\text { cases } 7 \text { and } 12\end{array}$ \\
\hline 21 & $\mathrm{M}$ & 37 & $\mathrm{SAB}, \mathrm{HH} 1$ & right middle cerebral artery & 1 & 2.5 i.D. & clip & yes & no \\
\hline 22 & M & 29 & SAB, HH1 & anterior communicating artery & 1 & 3 i.D & clip & yes & $\begin{array}{l}\text { later*; } \\
\text { relative of } \\
\text { case } 2\end{array}$ \\
\hline
\end{tabular}


Table 1 (continued)

\begin{tabular}{|c|c|c|c|c|c|c|c|c|c|}
\hline $\begin{array}{l}\text { Case } \\
\text { No. }\end{array}$ & Sex & $\begin{array}{l}\text { Age at } \\
\text { diagnosis } \\
\text { of IA } \\
\text { years }\end{array}$ & $\begin{array}{l}\text { Symptoms, } \\
\text { HH scale }\end{array}$ & Location of IAs & IAs, $\mathrm{n}$ & Size of IA, mm & Therapy & $\begin{array}{l}\text { Diagnosis } \\
\text { of IA before } \\
\text { ESRF }\end{array}$ & $\begin{array}{l}\text { Family history of } \\
\text { IAs }\end{array}$ \\
\hline 23 & $\mathrm{~F}$ & 49 & $\begin{array}{l}\text { SAB, } \mathrm{HH} 1 \text {, } \\
\text { Fisher } 2\end{array}$ & ophthalmic artery $3 \times$ & 3 & $\begin{array}{l}1.5 \text { i.D, } 2.2 \text { i.D., } \\
\text { 2.5 i.D. }\end{array}$ & coil, clip $2 \times$ & yes & no \\
\hline 24 & $\mathrm{~F}$ & $29 / 50$ & $\begin{array}{l}\mathrm{SAB} / \\
\mathrm{SAB} \\
\mathrm{HH} 2-3\end{array}$ & $\begin{array}{l}\text { anterior communicating artery, } \\
\text { right internal carotid artery }\end{array}$ & 2 & 2 i.D. & $\begin{array}{l}\text { clip } 2 \times \text { in } \\
21 \text { years }\end{array}$ & yes & no \\
\hline 25 & $\mathrm{~F}$ & 33 & $\mathrm{SDB}, \mathrm{HH} 2$ & left vertebral artery & 1 & n.a. & coil & yes & no \\
\hline 26 & M & 42 & sy & anterior communicating artery & 1 & n.a. & clip & yes & no \\
\hline 27 & $\mathrm{~F}$ & 50 & sy & left middle cerebral artery & 1 & n.a. & clip & yes & no \\
\hline 28 & M & 42 & sy & anterior communicating artery & 1 & n.a. & clip & yes & $\begin{array}{l}\text { relative of } \\
\text { cases } 5 \text { and } 6\end{array}$ \\
\hline 29 & $\mathrm{~F}$ & 27 & sy & n.a. & 1 & $9.5 \times 7.9 \times 10.6$ & n.a. & yes & $\begin{array}{l}\text { father with } \\
\text { cerebral } \\
\text { hemorrhage }\end{array}$ \\
\hline 30 & $\mathrm{~F}$ & 57 & sy & $\begin{array}{l}2 \times \text { right middle cerebral } \\
\text { artery and anterior } \\
\text { communicating artery }\end{array}$ & 3 & n.a. & $\begin{array}{l}\text { middle right } \\
\text { cerebral artery clip, } \\
\text { others not treated }\end{array}$ & no & no \\
\hline 31 & $\mathrm{~F}$ & 2 & sy & n.a. & 1 & n.a. & clip & yes & no \\
\hline 32 & $\mathrm{~F}$ & 48 & sy & $\begin{array}{l}2 \times \text { left middle cerebral artery, } \\
\text { left pericallosal artery and left } \\
\text { callosomarginal artery }\end{array}$ & 4 & n.a. & $\begin{array}{l}3 \times \text { coil } \\
1 \times \text { clip }\end{array}$ & no & no \\
\hline
\end{tabular}

Cases 5, 6, and 29 are members of the same family, cases 2 and 22 are from another family, and cases 7,12 , and 20 from a 3 rd family. $\mathrm{HH}=$ Cerebral dysfunction according to the Hunt and Hess grading scale; ESRD = end-stage renal disease; sy = symptomatic; asy = asymptomatic; $\mathrm{SAB}=$ subarachnoid hemorrhage; n.a. = data not available; i.D. = in diameter. ${ }^{*}$ The family history of IAs for this case was clarified by our study and was not known to the patient.

ditional patients had clipping in one and coiling in another session for multiple IAs. Four patients with asymptomatic aneurysms were not treated, and for 1 patient treatment data were not available.

The questionnaire regarding exclusion of IAs were answered by the patients or their providers for a total of 320 patients. MRI was performed in 59, CT in 12 and MR angiography in only $14 \%(45 / 320)$ of the patients. 69 patients had no neuroradiological imaging.

Of 463 registrants with ADPKD who had clinical data regarding presence or absence of IAs, 228 were found to have germline mutations in PKD1 or PKD2. Of these 228, 16 unrelated mutation-positive ADPKD patients also had IAs, yielding a prevalence of $7 \%$ of IAs in our series of mutation-positive ADPKD patients. These 16 patients comprised $11 \mathrm{fe}-$ males and 5 males with age at diagnosis of IA 2-57 (mean 41.5) years. Fourteen of the patients had mutations in the PKD1 gene and 2 in the PKD2 gene (tables 2, 3). The PKD1 mutations were of the following types: 4 missense, 1 splice site, 1 small insertion, and 8 small deletions. The 2 PKD2 mutations were of missense type. Of the mutations described here, 7 have never been described (http://pkdb.mayo.edu/cgi-bin/mutations.cgi). In particular, the mutations are spread over the exons of the PKD1 gene involving exons 7, 10, 11, $15,19,24,27,38,42$, and 43.

Mutation testing was particularly useful in a girl (case 31; table 1) who was diagnosed and operated on an IA at age 2 years and reached end-stage renal failure by age 21 years. The initial assumption was that she had autosomal recessive PKD. However, clinical signs of liver involvement by cholangiodysplasia and liver fibrosis were absent. A PKD1 germline muta- 

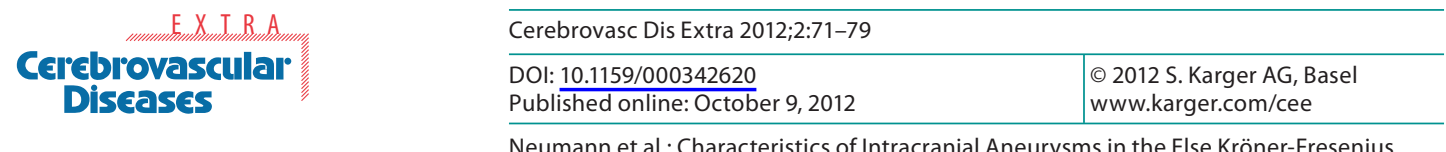

Neumann et al.: Characteristics of Intracranial Aneurysms in the Else Kröner-Fresenius

Registry of Autosomal Dominant Polycystic Kidney Disease

Table 2. Mutations of the $P K D 1$ gene in 17 patients with IAs

\begin{tabular}{|c|c|c|c|c|c|}
\hline $\begin{array}{l}\text { Case } \\
\text { No. }\end{array}$ & Exon & $\begin{array}{l}\text { Kind of } \\
\text { mutation }\end{array}$ & Mutation & Amino acid & Established \\
\hline 3 & 7 & frameshift & 1602 del C & p. Gly 535 Glu fs $\times 23$ & no* $^{*}$ \\
\hline 27 & 10 & frameshift & 2054_2055 del AG & p. Glu $685 \mathrm{Val}$ fs $\times 28$ & definitely pathogenic \\
\hline $5,6,29$ & 19 & frameshift & 7575_7576 del CT & p. Phe 2525 Leu fs $\times 69$ & no* \\
\hline 30 & 19 & missense & $7601 \mathrm{G} / \mathrm{C}$ & S $2534 \mathrm{~T}$ & no $^{*}$ \\
\hline \multirow[t]{3}{*}{13} & 23 & missense & $8279 \mathrm{C} / \mathrm{T}$ & M $2760 \mathrm{~T}$ & $\mathrm{no}^{*}$ \\
\hline & & & $8282 \mathrm{G} / \mathrm{C}$ & 0R $2761 \mathrm{P}$ & \\
\hline & & & $8291 \mathrm{~T} / \mathrm{C}$ & M 2764 T & \\
\hline 31 & 24 & splice & $8792-2 \mathrm{~A} / \mathrm{C}$ & Splice & likely pathogenic \\
\hline 32 & 27 & missense & 9398 G/A & G 3133 D & $\mathrm{no}^{*}$ \\
\hline 8 & 37 & frameshift & $10840 \mathrm{del} \mathrm{T}$ & p. Tyr 3614 Thr fs $\times 18$ & $\mathrm{no}^{*}$ \\
\hline 18 & 38 & frameshift & 11134 del C & p. Arg 3712 Gly fs $\times 114$ & $\mathrm{no}^{*}$ \\
\hline 2,23 & 42 & frameshift & 11554 del C & p. Leu $3852 \operatorname{Trp}$ fs $\times 93$ & $\mathrm{no}^{*}$ \\
\hline 16 & 43 & missense & $11717 \mathrm{G} / \mathrm{T}$ & C $3906 \mathrm{~F}$ & $\mathrm{no}^{*}$ \\
\hline 17 & $11 \mathrm{~b}$ & frameshift & 2644_2645 dup GT & p. Pro 883 Cys fs $\times 16$ & $\mathrm{no}^{*}$ \\
\hline 4 & $15 \mathrm{~d}$ & frameshift & 5014_5015 del AG & p. Arg 1672 Gly fs $\times 98$ & definitely pathogenic \\
\hline 28 & $15 \mathrm{f}$ & frameshift & 5997_6004 del 8 bp & p. Ser 2000 Arg fs $\times 47$ & likely pathogenic \\
\hline
\end{tabular}

Table 3. Mutations of the $P K D 2$ gene in 2 patients with IAs

\begin{tabular}{llllll}
\hline Case No. & Exon & Kind of mutation & Mutation & Amino acid & Established \\
\hline 14 & 4 & missense & $964 \mathrm{C} / \mathrm{T}$ & R 322 W & highly likely pathogenic \\
15 & 13 & missense & $2420 \mathrm{G} / \mathrm{A}$ & R 807 Q & undetermined \\
\hline
\end{tabular}

tion of missense type was identified in this patient, which was not seen in $>200$ control chromosomes and affecting a highly conserved DNA sequence, thus revealing the diagnosis of ADPKD by molecular means.

\section{Discussion}

While the consequences of unrecognized IAs are deadly, multiple studies have shown that the risk-benefit ratio is disadvantageous in indiscriminate surveillance of IAs and prophylactic treatment. However, it is suggested that surveillance and prophylactic treatment of individuals at high risk of IAs may yield a good risk-benefit profile [20]. IAs can occur sporadically or individuals can be genetically predisposed. Individuals who are genetically predisposed to IAs can be viewed as the subset of high-risk individuals who may benefit from routine surveillance and management. Heritable disorders with IAs as a component include Marfan syndrome [21], Ehlers-Danlos syndrome [22], Alport syndrome [23], and fibromuscular dysplasia $[24,25]$. In addition, we have described IAs in autosomal recessive PKD-associated multiple cerebral aneurysms [2]. The majority of hereditary IAs, however, occur in ADPKD [3]; yet, IA surveillance without a family history of IA is not currently recommended $[4,9,11]$. 
Thus, we aimed to determine the frequency and characteristics of IAs in ADPKD and were looking for demographic and clinical clues to guide surveillance and timing of surveillance.

Here, we present demographic, clinical, and molecular genetic data of 32 patients with IAs out of a total of 463 patients (7\%) from the population-based Else Kröner-Fresenius Registry for ADPKD for whom central nervous system imaging data were available. The prevalence of unruptured IAs in the general population is about 3\%, but in ADPKD it is about 7\% according to a meta-analysis [26]. In our current population-based series, 12 of 32 ADPKD patients (38\%) with IAs presented with asymptomatic IAs, representing $2.4 \%(12 / 491)$ of all ADPKD patients.

The clinical data from these ADPKD-related IA patients were revealing in 3 ways. First, $>90 \%$ (29/32) of ADPKD patients detected with IAs were older than 30 years of age. This contrasts with other observations which report that IAs are only occasionally the presenting manifestation of ADPKD [4]. Second, most patients $(26 / 32,81 \%)$ showed IAs before reaching end-stage renal failure. Thus, these patients are far less frequently seen by physicians compared to those on dialysis who have three renal replacement treatments on hemodialysis per week or are regularly seen by nephrologists if on chronic ambulatory peritoneal dialysis. Consequently, the majority of patients with IAs run a high risk of being diagnosed late. The third and most important result of this study is the frequent absence of hints of IAs in the given ADPKD families. A history of IAs was initially present in only 2 families (1st family: cases 7,12 , and 20; 2 nd family: case 15 ; table 1), whereas in a third family (case 28; table 1), cerebral hemorrhage indicated that an aneurysm might have been present. In two additional families, relatives with ADPKD proved to have IAs after IAs had been detected in the index cases (relatives of case 28: cases 5 and 6; relative of case 2: case 22; table 1). Thus, only a maximum of 5 of 27 families (19\%) including patients with IAs had familial clustering of IAs, but the overwhelming majority of index cases had no clearly documented IAs in relatives at the time when the IA was diagnosed in the index case (25/27 index cases, 93\%). In contrast to the expectation of multifocal involvement in a hereditary disorder, only 12 out of 321 patients (38\%) had multiple aneurysms.

From the molecular genetic viewpoint, IAs occurred in patients with mutations in both the PKD1 gene and the PKD2 gene. The mutations in both genes comprise missense, splice site, small deletions, and small insertions. The mutations identified in this study do not show a clustering within certain areas of the genes, i.e. in the $5^{\prime}$ region of $P K D 1$ as reported by others [4]. Thus, the molecular genetic results may not add substantial predictive value to identify risk for IAs in ADPKD patients.

Our study is particularly timely in the context of an ongoing debate on whether general surveillance of IAs in ADPKD is warranted [11]. Two studies did not suggest an increased risk for growth and rupture in initially unruptured IAs in ADPKD compared to IAs in the general population; therefore, a widespread screening for unruptured IAs in ADPKD was not recommended [11,27]. Our current data, however, raise doubts. Based on our data, we suggest that all patients with ADPKD older than 30 years of age should undergo a baseline screen for IAs. The state of the art technique is magnetic resonance angiography, which can be easily performed without contrast medium and appears to be cost-effective [20]. It is astonishing that despite the known risk for IAs in ADPKD, only $14 \%$ of 320 patients of this series classified as not having IAs had been sufficientyly investigated by MR angiography.

In conclusion, IAs occurring in ADPKD are associated with germline mutations of the $P K D 1$ and PKD2 genes. Virtually all IAs occur after the age of 30 years, before onset of endstage renal failure, and rarely in a setting of families with known cerebral events. We also showed a risk of rupture with sequelae. Our data support that screening for IAs should not be restricted to individuals whose families have a history of cerebral events and should be started before end stage renal failure. 


\section{Cerebrovascular Diseases}

Cerebrovasc Dis Extra 2012;2:71-79

DOI: $10.1159 / 000342620$

Published online: October 9, 2012

Neumann et al.: Characteristics of Intracranial Aneurysms in the Else Kröner-Fresenius

Registry of Autosomal Dominant Polycystic Kidney Disease

\section{Acknowledgement}

We acknowledge the support of this study by Dr. Sodemann, Lahr, Dr. Henke, Radolfzell, Dr. Weinreich, Villingen-Schwenningen, and Dr. Schnierda, Waldshut. The study has been supported by the Else Kröner-Fresenius Foundation Grant 2009_A75.

\section{References}

-1 Rinkel GJ: Natural history, epidemiology and screening of unruptured intracranial aneurysms. Rev Neurol (Paris) 2008;164:781-786.

-2 Neumann HP, Krumme B, van Velthoven V, Orszagh M, Zerres K: Multiple intracranial aneurysms in a patient with autosomal recessive polycystic kidney disease. Nephrol Dial Transplant 1999;14: 936-939.

-3 Gabow PA: Autosomal dominant polycystic kidney disease. N Engl J Med 1993;329:332-342.

4 Torres VE, Harris PC, Pirson Y: Autosomal dominant polycystic kidney disease. Lancet 2007;369: $1287-1301$.

-5 Xu HW, Yu SQ, Mei CL, Li MH: Screening for intracranial aneurysm in 355 patients with autosomaldominant polycystic kidney disease. Stroke 2011;42:204-206.

-6 van der Kolk NM, Algra A, Rinkel GJ: Risk of aneurysm rupture at intracranial arterial bifurcations. Cerebrovasc Dis 2010;30:29-35.

-7 Shiue I, Arima H, Hankey GJ, Anderson CS: Location and size of ruptured intracranial aneurysm and serious clinical outcomes early after subarachnoid hemorrhage: a population-based study in Australasia. Cerebrovasc Dis 2011;31:573-579.

-8 Hunt WE, Hess RM: Surgical risk as related to time of intervention in the repair of intracranial aneurysms. J Neurosurg 1968;28:14-20.

9 Unruptured intracranial aneurysms - risk of rupture and risks of surgical intervention. International Study of Unruptured Intracranial Aneurysms Investigators. N Engl J Med 1998;339:1725-1733.

-10 Akiyama Y, Houkin K, Nozaki K, Hashimoto N: Practical decision-making in the treatment of unruptured cerebral aneurysm in Japan: the U-CARE study. Cerebrovasc Dis 2010;30:491-499.

-11 Irazabal MV, Huston J 3rd, Kubly V, Rossetti S, Sundsbak JL, Hogan MC, Harris PC, Brown RD Jr, Torres VE: Extended follow-up of unruptured intracranial aneurysms detected by presymptomatic screening in patients with autosomal dominant polycystic kidney disease. Clin J Am Soc Nephrol 2011;6:1274-1285.

12 Harris PC, Torres VE: Polycystic kidney disease, autosomal dominant; in Pagon RA, Bird TD, Dolan CR, Stephens K, Adam MP (eds): Gene Reviews (Internet). Seattle, University of Washington, 2011.

13 Neumann HP, Bacher J, Nabulsi Z, Ortiz Brüchle N, Hoffmann MM, Schaeffner E, Nürnberger J, Cybulla M, Wilpert J, Riegler P, Corradini R, Kraemer-Guth A, Azurmendi P, Nunez M, Gläsker S, Zerres K, Jilg C: Adult patients with sporadic polycystic kidney disease: the importance of screening for mutations in the PKD1 and PKD2 genes. Int Urol Nephrol 2012, E-pub ahead of print.

-14 Rossetti S, Chauveau D, Walker D, Saggar-Malik A, Winearls CG, Torres VE, Harris PC: A complete mutation screen of the ADPKD genes by DHPLC. Kidney Int 2002;61:1588-1599.

-15 Grantham R: Amino acid difference formula to help explain protein evolution. Science 1974;185: 862-864.

-16 Ng PC, Henikoff S: Predicting the effects of amino acid substitutions on protein function. Annu Rev Genomics Hum Genet 2006;7:61-80.

17 Ramensky V, Bork P, Sunyaev S: Human non-synonymous SNPs: server and survey. Nucleic Acids Res 2002;30:3894-3900.

- 18 Schwarz JM, Rodelsperger C, Schuelke M, Seelow D: MutationTaster evaluates disease-causing potential of sequence alterations. Nat Methods 2010;7:575-576.

-19 Thorn KS, Bogan AA: ASEdb: a database of alanine mutations and their effects on the free energy of binding in protein interactions. Bioinformatics 2001;17:284-285.

-20 Bor AS, Koffijberg H, Wermer MJ, Rinkel GJ: Optimal screening strategy for familial intracranial aneurysms: a cost-effectiveness analysis. Neurology 2010;74:1671-1679. 
21 Schievink WI: Marfan syndrome and intracranial aneurysms. Stroke 1999;30:2767-2768.

-22 Pepin M, Schwarze U, Superti-Furga A, Byers PH: Clinical and genetic features of Ehlers-Danlos syndrome type IV, the vascular type. N Engl J Med 2000;342:673-680.

-23 Vaicys C, Hunt CD, Heary RF: Ruptured intracranial aneurysm in an adolescent with Alport's syndrome - a new expression of type IV collagenopathy: case report. Surg Neurol 2000;54:68-72.

-24 Cloft HJ, Kallmes DF, Kallmes MH, Goldstein JH, Jensen ME, Dion JE: Prevalence of cerebral aneurysms in patients with fibromuscular dysplasia: a reassessment. J Neurosurg 1998;88:436-440.

-25 van den Berg JS, Hennekam RC, Cruysberg JR, Steijlen PM, Swart J, Tijmes N, Limburg M: Prevalence of symptomatic intracranial aneurysm and ischaemic stroke in pseudoxanthoma elasticum. Cerebrovasc Dis 2000;10:315-319.

-26 Vlak MH, Algra A, Brandenburg R, Rinkel GJ: Prevalence of unruptured intracranial aneurysms, with emphasis on sex, age, comorbidity, country, and time period: a systematic review and metaanalysis. Lancet Neurol 2011;10:626-636.

-27 Gibbs GF, Huston J 3rd, Qian Q, Kubly V, Harris PC, Brown RD Jr, Torres VE: Follow-up of intracranial aneurysms in autosomal-dominant polycystic kidney disease. Kidney Int 2004;65:1621-1627. 